Article

\title{
Board Games as Interview Tools: Creating a Safe Space for Unaccompanied Refugee Children
}

\author{
Annamária Neag \\ Centre for Excellence in Media Practice, Bournemouth University, Poole, BH12 5BB, UK; E-Mail: aneag@bournemouth.ac.uk
}

Submitted: 9 November 2018 | Accepted: 3 May 2019 | Published: 28 June 2019

\begin{abstract}
Since the emergence of the new sociology of childhood in the late 1980s, there has been an increasing expectation to engage children actively and to take their views seriously throughout the research process. This is even more important when it comes to unaccompanied refugee children, whose voice is seldom heard. In this article the author builds upon her project of exploring unaccompanied refugee children's lived media experiences and argues that-in order to have meaningful results and to create safe spaces for those who need it most-we need to search beyond traditional research tools. Specifically, she proposes to bring into research the concept of "play". The article presents the use of bespoke, artisanal board games in cross-national interview settings with unaccompanied refugee children. It is argued that these creative tools can help in collecting diverse and rich data that can successfully complement traditional research methods.
\end{abstract}

\section{Keywords}

unaccompanied refugee children; board games; interviewing; media literacy; qualitative methods

\section{Issue}

This article is part of the issue "Refugee Crises Disclosed: Intersections between Media, Communication and Forced Migration Processes", edited by Vasiliki Tsagkroni (Leiden University, The Netherlands) and Amanda Alencar (Erasmus University Rotterdam, The Netherlands).

(C) 2019 by the author; licensee Cogitatio (Lisbon, Portugal). This article is licensed under a Creative Commons Attribution 4.0 International License (CC BY).

\section{Introduction}

The latest UNICEF State of the World's Children report contains a statement that today is perhaps more important than ever: "Children use digital technology for specific reasons and it is important to take their opinions and explanations seriously" (2017, p. 119). In the last decades, a growing number of scholars have been advocating for making children's voices heard in scientific research (Cannella, 1997; MacNaughton \& Smith, 2015; O'Loughlin, 2001; etc.). However, there are specific difficulties in researching children's and teenagers' perspectives and even with the best of intentions, it is sometimes quite challenging to navigate through the many rules and recommendations that need to be taken into consideration. While some of the issues, such as creating safe spaces where children feel comfortable (MacNaughton \& Smith, 2015), are crucial and obvious, others, like the increasing surveillance of children in re- search (James \& Prout, 1997) can hinder projects. These difficulties are further compounded, if one is interested in the perspectives of unaccompanied refugee children, as I was, through a project that investigated the digital and social media use of these children, after their arrival to Europe. Moreover, specific ethical and methodological considerations have to be acknowledged when it comes to researching unaccompanied minor refugees. Apart from the well-known issue of these children's vulnerability, one has to consider the specific life experiences and difficulties of those migrating without parents or guardians (Hopkins, 2008). Previous research studies have also drawn attention to the question of failing to understand cultural nuances and sensitivities (Jacobsen \& Landau, 2003; Kabranian-Melkonian, 2015; Voutira \& Doná, 2007); the importance of using gatekeepers to access the field (Charmarkeh, 2013); or the importance of "highly charged policy and political environments" (Schmidt, 2007, p. 92) in influencing method- 
ological choices. Similarly, we are also reminded that:

Knowledge production within the social sciences and humanities tends to be culturally specific, and as a consequence, the particular knowledge generated is designed to articulate particular and most often Eurocentric ideological and philosophical worldviews, and further serves the interests of proponents of those ideologies and world views. (Blay, 2008, p. 61)

The aim of this article, however, is not to focus on the main difficulties in doing research with unaccompanied refugee children, but rather to present a unique approach to interviewing that proved to be successful in gaining in-depth data. The research tool used (a board game) helped overcome some of the issues highlighted above by addressing the challenges of vulnerability, cultural differences and diverging world views through focusing on the universal language of "play". The research project that this article draws upon was a twoyear long cross-national study that analysed unaccompanied refugee children's (social) media experiences in the Netherlands, Sweden and Italy. These three European countries had the largest share of unaccompanied minors among asylum seekers at the time of the research design (Eurostat, 2016). A total of 56 young people participated in this project: in terms of nationalities, most of the teenagers came from Eritrea (16), Afghanistan (15), Morocco (4), Somalia (4), with one or two participants coming from other Middle Eastern, African or South Asian countries. In terms of gender distribution, most of the participants were boys, with 11 girls participating in this study. The field-work lasted for two weeks in each country. The project aimed to understand their media use in order to create media literacy educational materials that can help these children in becoming critical media users and creators. The research relied on a mix of qualitative methods that involved an online media diary, participant observation, interviews and digital ethnography. This methodology is in line with what Yalaz and Zapata-Barrero (2018) note as an increasing focus on employing qualitative methodology in the field of migration studies. Qualitative projects are becoming more prominent as these produce nuanced and rich data (Morawska, 2018). In terms of methods then, most projects in this field are reliant upon interviews, participant observation, focus groups, historical analysis, and much less on internet-mediated research or visual analysis (Yalaz \& Zapata-Barrero, 2018, p. 15). From this analysis it is clear that more "unconventional" qualitative research methods are perhaps used by researchers, but are not frequently reported in key migration journals, in spite of the fact that scholars have advocated the use of collaborative and participatory projects as early as 2007 (e.g., Ellis, KiaKeating, Siraad, Lincoln, \& Nur, 2007). In the last couple of years some methods such as photo-elicitation within participatory action research or ethnographic films have started gaining attention (e.g., Francisco, 2014; Leurs,
Omerovic, Bruinenberg, \& Sprenger, 2018). In light of recent developments, I aim to strengthen these initiatives by focusing on creative research methods in the field of migration studies. More specifically then, the goal of this article is to present the use of artisanal board games in research settings. Through these board games, the interaction with the unaccompanied refugee youth provided not only much richer data, but also an opportunity to transform an otherwise formal "traditional" interview setting into one that evolved around the concept of "play". For education scholars, such as Eugen Fink (1960, p. 101):

Play is itself a fundamental phenomenon of existence...we play with the serious, the authentic, the real. We play with work and struggle, love and death. We even play with play...joy reigns in it as undisputed master at each moment, carrying it forward and giving it wings...it is a joy rooted in the most special...activity, open to many interpretations. It can include profound sadness, a tragic suffering. It can embrace the most striking contraries...[m]oved to tears we may be, we smile at the comedy and tragedy which are our life and which the play represents to us.

In the digital world in which our unaccompanied refugee youth operate at the fringes of, "play can be the beginning of a conversation (dialogue) which children begin to have with different texts and experiences" (Berger \& Zezulkova, 2016, p. 3). In this note then, I will first position the study in the context of digital migration studies, and then focus on the methodological choices that were made based on the experiences of the field work and on my re-considering of the traditional interviewing methods. The article ends by reflecting on the possibilities of altering our research approaches, in order to create a more equal relationship between researchers and participants.

\section{Researching Migration and Digital Media Use}

By 2017, more than 150,000 unaccompanied minor asylum-seekers reached Europe (Eurostat, 2017). Mass media reported intensely on how smart phones became crucial tools for young people during their journey, with Google-map functionality, for instance, playing a crucial role in assisting families and unaccompanied children navigating themselves out of the crisis zones across the Middle-East and Africa. Recent scholarship focusing on information and communications technology use by refugees on their migration journey highlighted that most of refugees have relevant IT skills, but with the plethora of information available, they do not know whom to trust (Gillespie et al., 2016). After this journey, unaccompanied children and teenagers have had to further navigate themselves through the physical and digital haze of European public systems, cultures, and institutions. Kutscher and Kreß (2018) highlight in their arti- 
cle that digital media became a basic necessity for everyday life for unaccompanied refugee children in the new home countries. Moreover, social media networking sites were also found to be important for refugees in the process of language learning and forging new relationships (Alencar, 2017).

Despite the ubiquitousness of smart phones and social media, an important question that has to be answered is whether digital technology and media can be a useful tool for tackling the challenges of building a new home. In servicing the research aim of creating media literacy education materials, it was imperative first to explore everyday media practices among unaccompanied refugee children seeking asylum in EU nations. As previously mentioned, the fieldwork was carried out in three EU countries, as multi-sited ethnography is essential when one wants to understand migration as a human process that itself is about crossing borders and mobility. FitzGerald (2012) further argues that it is important to do comparative studies of migration, in order to be able to analyse both similarities and contrasts and to overcome "methodological nationalism" (p. 1731). In order to counteract the criticism that multi-sited research loses the deeper knowledge of a locality (FitzGerald, 2012), I collaborated with local academics and NGO experts in order to combine their insider understanding and my own outsider fresh perspective.

In terms of research strategy, it was important to adopt one that is as complex as "the object of the study itself" (Beneito-Montagut, 2011, p. 725). Scholars highlight the fact that the methods used to study the social practices of young people have to take into consideration key issues, such as the blurring of the boundaries between their online and offline experiences or the importance of young people's self-representation and performativity in the online world (Vittadini, Carlo, Gilje, Laursen, Murru, \& Schrøder, 2014). Researchers are now noticing that, "teens struggle to make sense of the networked publics they inhabit-and the ways in which their practices reveal cultural fractures-highlight some of the challenges society faces as technology gets integrated into daily life" (Boyd, 2014, p. 212). Related studies with digitally connected youth have found that, "[o]nline communication seemed to reinforce (rather than undermine) the importance of relationships with family and local friends, built primarily through face-to-face communication" (Livingstone \& Sefton-Green, 2016, p. 84). I was interested thus in whether these previous findings can be replicated in the case of unaccompanied refugee children.

\section{The Messiness of the Research Process}

The initial research design was intended to capture the lived media experience of unaccompanied refugee children (aged 14-18) through a combination of semistructured interviews, participant observation and the use of an online media diary. We built this online me- dia diary upon the principles of participant-driven diary studies, a type of diary study in which participants use media to record events (Carter \& Mankoff, 2005). We customised it to mobile devices and translated into Tigrinya and Arabic, the two most used languages among refugee children in the Netherlands, the country chosen for the pilot project. The participants were contacted through NGOs who acted as gate-keepers. I was invited to present the research project to young people, who could ask questions and voice their opinions about it. They could then decide whether they wanted to participate, based on the presentation and on information sheets that were available in English, Arabic and Tigrinya.

Upon entering the field and carrying out the initial interviews with the young people, it became immediately apparent that doing field work can become a messy endeavour. Although in many instances, the research process is presented as a straightforward, precise practice (Lambotte \& Meunier, 2013), I realised that in this case, the research tools would have to be substantially readjusted to the local conditions and contexts. Although the online media diary was purposefully created in an accessible manner for these children, and the I explained in detail the use of this tool after the interviews, the young people did not engage with it as thoroughly as was envisaged. The reasons why they did not fill in the online diary were varied: some of them were illiterate, while others were not accustomed to writing longer texts. Some others then did not feel secure in sharing information about their media experiences in their diaries. This was similar to what Block, Warr, Gibbs and Riggs's (2013) experienced with migrant youth in Australia. Just as in our case, the Australian research team chose a specific method (focus groups), because this method is regularly used with vulnerable groups, as it can give participants more control over the process. However, they also found that the chosen method did not help in eliciting meaningful responses (Block et al., 2013).

Therefore, it was necessary to re-set and build a research tool that can more effectively capture broadly the similar data as the online media diary would have had. The main condition that had to be taken into consideration was that I needed a tool that can be used during the interviews, as I found that the refugee children were unlikely to take part 'remotely' in the research, by filling in an online diary. This was not because they needed adult supervision in anyway. I could infer from my first experiences that unaccompanied refugee youth live very much in the immediate moment, and previous research shows that the future is always an uncertain prospect for displaced and state-less peoples (El-Shaarawi, 2012). For this reason, I was compelled to go beyond the advice to use research methods that complement each other and help in understanding a complex reality (Vittadini et al., 2014); I needed a tool that engages unaccompanied refugee children.

Another aspect that I had to consider was power imbalances. Uncertainty about the roles and powers of 
different people and organisations in a specific refugee situation influences not only verbal answers-often designed to fit what a respondent may see as a reasonable expectation to have from outsiders-but also habits of interaction. This power asymmetry between researchers and participants has been critiqued, for instance, by Bourdieu (1996), who also highlights the social asymmetry, that happens when the "investigator occupies a higher place in the social hierarchy" (Bourdieu, 1996, p. 19). Often the questions refugees are asked by researchers and agencies overlap. As a similar research project notes: "many of our interviewees were unable or unwilling to distinguish between our role as researchers, and the role played by a needs assessment team" (Hovil, Lomo, \& Kaiser, 2005, p. 45). And finally, because the process of migration is so politically charged, Leurs and Smets (2018) remind us that the figure of 'the migrant' is performatively constructed and that "researchers are complicit in this process" (p. 10).

Although it is well-known that research with children has to be more captivating, it is important to consider relational ethics (Ellis, 2007) when it comes to researching the media worlds of unaccompanied refugee children. Relational ethics has been defined as being "true to one's character and responsible for one's actions and their consequences on others" (Slattery \& Rapp, 2003, p. 55). More specifically then, mutual respect, dignity and connectedness are the values recognised by relational ethics (Ellis, 2007). While respect and dignity were values imbedded in the interview situation, I aimed to create a research tool that could build a more playful connectedness between researcher and participants.

A different element that I had to consider is the pervasiveness of the digital world. However, the experience of the pilot project suggested an approach that involves both the "new" (apps, smart phones) and a return to the "basics" (regular play). Moreover, as I watched young people play football in the courtyards of their accommodation centres-from countries vastly different, such as Afghanistan or Eritrea-I realised that "playing" can become a "language" that all children are familiar with. Another reason for deciding upon using a board game were the two main characteristics of play, as noted by Huizinga (1949). One of these characteristics is that play is free, no one can be obliged to play (Huizinga, 1949), and in terms of relational ethics and unaccompanied refugee children, this is extremely important. The other feature of play is that it is not "ordinary" life: "it is rather a stepping out of «real» life into a temporary sphere of activity with a disposition all of its own" (Huizinga, 1949, p. 9). With vulnerable participants, the option of offering a possibility to "leave" the difficult everyday realities even for just a limited time, it seemed to be a something worth exploring. Therefore, together with an artist, we turned our attention towards making a creative research tool that could capture unaccompanied refugee children's daily media use.

\section{Board Games as Creative Research Tools}

Researching children's experience has dramatically changed over the last couple of decades from seeing children as merely objects of research to children as subjects, as emphasized by the "new social studies of childhood" (Greene \& Hogan, 2005). In order to involve children and young people, creative methods have been proposed in order to "assist research participants to describe and analyse their experiences and give meaning to them" (Andersson et al., 2005, p. 1). Creative research methods (Gauntlett, 2007) have been gradually accepted in recent years across a multitude of academic fields. From storytelling to photo-elicitation, photovoice or drama, there have been a number of methods that researchers used to complement or replace data gathered through traditional methods. Researchers employing creative methods argue that these methods provide "new ways of understanding people's real lived experiences....and offer ways to give back and contribute to a community" (Vaart, Hoven, \& Huigen, 2018, p. 1). Similarly, children's visual methods are also becoming more popular in migration studies. Some of these studies make use of drawings (Fernandez, Liamputtong, \& Wallersheim, 2015; Liamputtong \& Fernandez, 2015) or mental maps (den Besten, 2010; Moskal, 2017) to gather data that otherwise cannot be obtained or to enrich findings. All these new ways of working sit very much outside the more "traditional" approaches to conducting research but are becoming more widely used.

Upon reflecting on the pilot experiences with my NGO contacts, it became clear that I needed to alter my approach in order to create a more playful and engaging communicative space with my participants. Participatory research is a type of research that is in essence "collaborative and aims to achieve social change from below" (Doná, 2007, p. 214). My aim was thus to use elements of participatory research in order to make the whole project process more cooperative. As a first step towards such an approach, I consulted with mentors and NGO professionals, and they advised to employ a method that uses less text and more images, and to transform the whole experience into one that is more interactive. While I could have chosen one of the existing creative research methods, after carefully balancing the pros and cons of each of these methods, I realised that I needed a tool that fulfils a number of criteria. First of all, I needed a tool that is not built on the premise that young people should create or prepare something before our interview (e.g., taking photos), as this proved to be challenging when I first tried to use the online media diary with them. Therefore, photo elicitation or photo voice had to be ruled out. A second important criteria was the need for a tool that it is easy to engage with for participants with different literacy skills and language knowledge. Storytelling or drama would have excluded those young people who felt unsecure about their language skills. And thirdly I needed a tool that builds upon 
something familiar to the young people, irrespective of their country of provenience. My attention, thus, turned to the universality of playing games and to the specific tool of board games.

The origins of board games go back to the sixth century BCE, when the world's oldest board game, "Go" ("Weiqi") was created in Asia (Driscoll, 2018). From divination purposes to imparting Christian values or teaching good manners, board games have always had an important role in society. As Donovan (2017) argues, across the centuries, board games always reflected the values of time. Board games also sit neatly on the axis between "play" and education, and gaming is becoming a useful element of a researcher's toolkit.

As a result, scholars started investigating the educational aspect of board games: Chou (2017), for instance, showed the role these games have in developing pupils' aesthetic experience and interpersonal understanding, while another study (Wu, Chen, \& Huang, 2014) confirmed the capacity of board games in encouraging communication and context-relevant immersion in English as Foreign Language classrooms. In the case of these two studies, the target groups were children or young learners, however, researchers have also looked at how board games can help in adult education. Mouton et al. (2017) investigated how a giant exercising board game can improve the overall health of nursing home residents, while Ladur, van Teijlingen and Hundley (2018) explored the possibility of using a board game in order to better engage Ugandan men to help improve health outcomes for pregnant women. A recent report discussing innovation in pedagogy, also highlights that play "evokes creativity, imagination, and happiness" (Ferguson et al., 2019, p. 3). Taking all this into consideration, in order to engage young unaccompanied refugees, I decided to create two board games that combined media experiences with regular everyday practices. Besides building upon the advices of NGO experts, I also involved in this creation process an artist. O'Donoghue (2011) argues that artists "will bring to research...very different ways of seeing, imagining, understanding, articulating, and inquiring, which leads to better questioning and more robust inquiry practices" (p. 649). Beyond helping with the visual design, this collaboration helped in refining my interview approach.

\section{Board Games for Unaccompanied Refugee Children}

The first board game was nicknamed the "app o'clock", as it explored the media experiences of refugee children's around the face of a clock (see Figure 1). Participants were asked to either talk about or write on a post-it-note the technology, websites, or apps they were using during the day.

The rule of the game was that they had to think about apps they use on a daily basis. For moving on the board game, one was asked to name an app/website she/he uses for a specific activity (e.g., during breakfast,

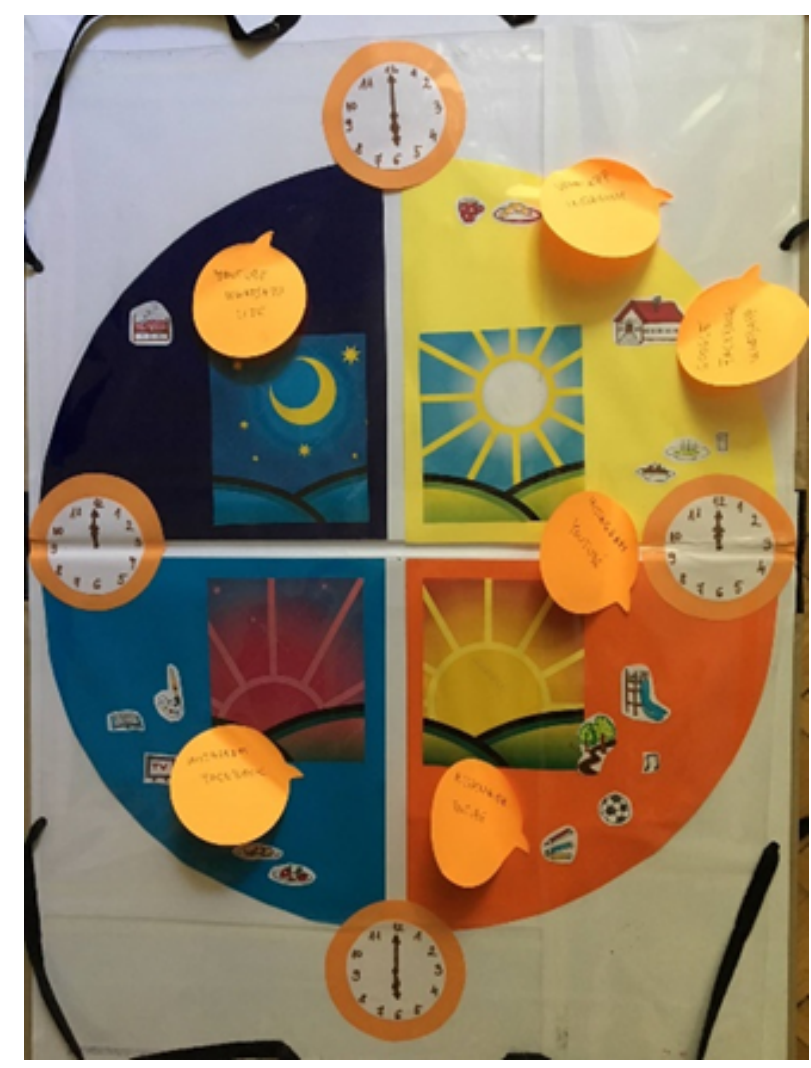

Figure 1. The "app o'clock".

at school, or during leisure activities). The activity proved to be a good "ice-breaker", as the participants were more open to talking about their everyday activities and how these tie-in with their phone use. An interesting aspect of the game was the interaction among the refugee children, as they sometimes made jokes, or they were surprised by each other's (over)reliance on social media, for instance. Beyond gathering relevant data, for the purpose of this project, the "app o'clock" proved to be a great tool for the children to reflect on how their lives has changed. While at no point of the "game" did I ask about their experiences during their journey to Europe, the participants while looking at the playing field were more prone to discuss how their use of technology differed to what they had used back home. In one of these instances, an Afghan boy, when he stepped on the "school field", and was asked about the regular websites he uses during that time, he mentioned Google Classroom. After this, he talked about how different school was in Sweden in comparison with Afghanistan:

It's too different because I didn't have a computer in Afghanistan and we have to write in Afghanistan in pen and notebooks, and we don't have too much notebooks here in Sweden because we're working on the computer all the time. (author's notes)

In terms of the aim of the overall project this information is then extremely valuable, as it shows how the transition from their home country to a new one has influenced 
unaccompanied young people's technology use. Moreover (and perhaps more importantly) it casts light on the everyday struggles of getting used to a new environment and the tenacity of those children who come to Europe on their own.

For the qualitative researcher then, it was an opportunity to become more reflexive and empathetic, and it provided a space for a better understanding of the lives of these children. While engaging with participants over seemingly mundane topics, such as a participant's favourite meal, the board game became a tool for a more equal relationship. In terms of rational approaches, one could argue that these "side discussions" offered no "real" empirical evidence. However, I argue that in the case of children, and moreover, unaccompanied refugee children, this first board game further drew quite defined lines of disembarkation between the researcher (and participants) and the other adults they would encounter, most of who had quite strong professional identities. Studies on post-migratory stress (Sack, 1998) have shown that unaccompanied refugee children struggle because of the difficulty to cope with new rules and regulations and the nightmare of navigating a "maze of systems" (Kohli \& Mather, 2003, p. 21). By "playing" a board game however, my aim was to open up a world of possibilities that was not led by a quest for data through any means possible, but by an approach in which all participants are more equal than in traditional research settings. In the vein of relational ethics (Ellis, 2007) then, this first board game created a ludic atmosphere where the researcher also shared personal stories, and thus a safe environment was created where children could openly talk about their experiences. For instance, during one of the interviews, with an Afghan girl, with the help of the board game we were going through her regular daily activities and the apps she uses. When she got to "lunch time", I humorously remarked that I am not a great cook, so I often need to look up recipes on the internet. At that point she wrote Youtube on the post-it and started telling me that she likes cooking and she also looks up recipes on the app:

Interviewer: And what kind of recipes do you look up? In what language?

Afghan girl: If I want to make a Persian dish, I look of course in Persian language, and if I want to make something Swedish, I will use Swedish, but if I want something like cupcakes, I will search in English. Depending on what I am looking for. (author's notes)

This seemingly prosaic discussion was actually incredibly relevant in understanding how unaccompanied young refugees use digital technology for solving everyday problems in their country of asylum. During the pilot project, before using the board games, I frequently received very short answers on how the young people were using apps. For instance, when asked about YouTube, the usual answer was that they use it to listen to music. However, as the above fragment shows, this specific app can mean much more to young people living without their parents, such as connecting them to the (food) culture left behind or the one recently discovered in the new country. The board game thus provided an opportunity for researcher and participants to share common (digital) experiences and connect through play.

Going further, the next step was to explore the use of pre-selected applications through a second artisanal board game (see Figure 2). I called this the "app board game".

Participants were asked to connect specific activities to apps they use for these activities. The apps they were able to choose from were created as laminated "buttons"

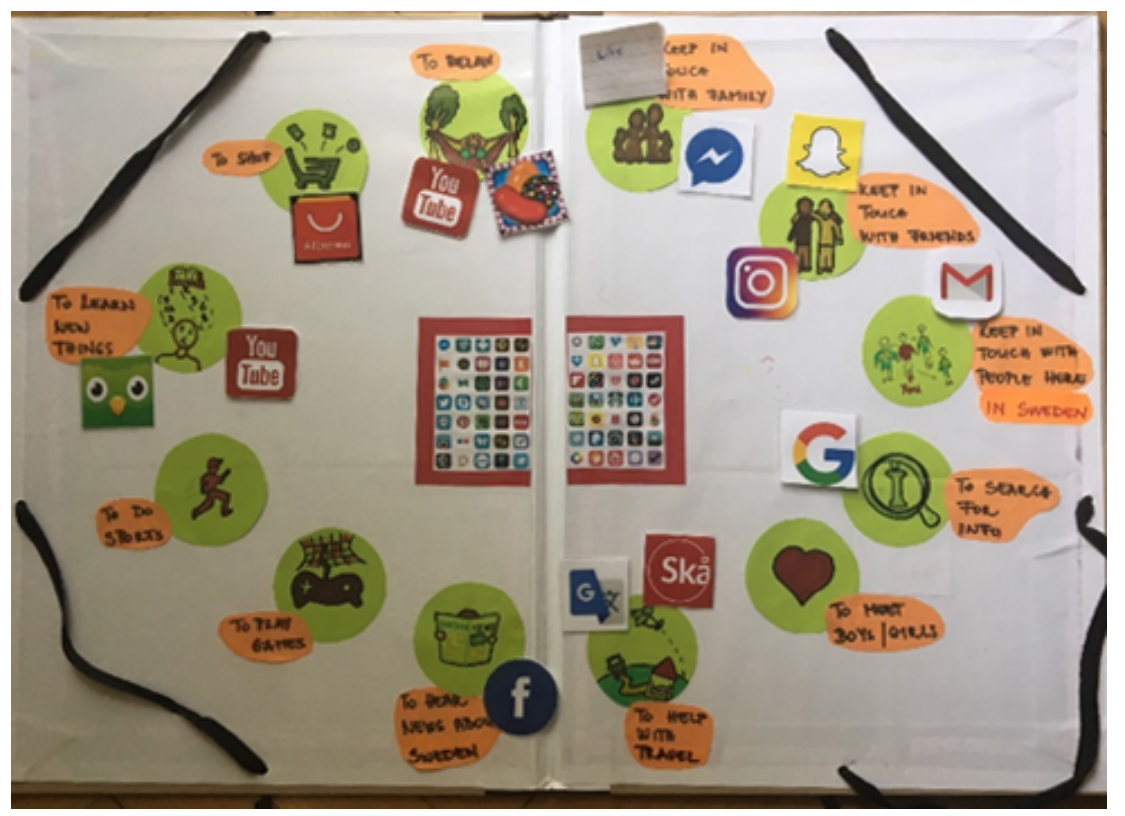

Figure 2. The "app board game". 
that could be moved around on the board. These buttons were reflecting the most popular applications in the country of the research, based on the number of downloads in the previous month, as reported by App Annie, an app market data platform. The participants were able to choose from more than 50 apps such as the one(s) they used for keeping in touch with friends, to shop online or to relax. In the case that a certain app they used was not among these buttons, the participants had the opportunity to create a new one on the spot. This way, the children could actively participate in the co-creation of the game. The second board game offered an opportunity for the young people to share their opinions about the apps they used the most. Apart from selecting a button, the game was an opportunity for them to consider their own media or social media use. This led to many "aha moments" when, for instance, a young person looking at the board, realised the over-reliance on some platforms. At the end of one of the interviews, a young Somali girl looked at the board and realised that there were basically two buttons (apps) used for most of her social interaction. She started laughing and admitted to being worried about being addicted to these:

[She is looking at the board and starts laughing:] It's all Snapchat and Facebook.

I sleep with Facebook. I sleep while I am talking on Facebook. Most of the time I use Facebook, I talk to a lot of people, Messenger [laughing]. (author's notes)

\section{Reflection on Using Board Games as Research Tools}

Many textbooks and articles highlight the requirement for academics to be flexible in order to adapt to specific research situations (e.g., Block et al., 2013). This project has showed us, however, that beyond being responsive to local conditions, one can think outside the traditional research tool box and bring into it elements from other aspects of life.

By using the two artisanal game boards, I found that in contrast with the pilot project, when answers were short and lacking depth, the children participated actively and were immersed into the game. One of the reasons of this was the fact that the board games were designed to appeal to children and young people. With colourful drawings and very little text, these board games offered a totally different experience to what the unaccompanied refugee children have previously seen when in formal interview settings. In line with Gauntlett's (2007, p. 182) argument, by using a creative research tool, participants communicated different kinds of information. So, I am not claiming here that I got "better" data, from side-lining more "traditional" approaches to research interviews, but I certainly feel that our tool, and the attendant activities, did produce "different" and more nuanced data.

In connection with this, however, I need to highlight some limitations of this research tool. One potential pit- fall lies exactly in its engaging and fun nature. While on one hand this can help in easing the pressure of a formal interview setting for children and teenagers, its use can also become ambiguous in case the participants think that they are only taking part in a game. This is why it was important for me to highlight that although it's a board game, the answers and information shared will be used for scientific purposes. A crucial aspect then is that of language use. During the games I would use either English (in Sweden), or Italian and English (in Italy), as the young people knew these languages to different degrees. This does not mean that the board games cannot be used when an interpreter is present. However, besides the well-known issues of interpreters' position in a community or their experience (see Bergen, 2018), when using board games, a researcher needs to consider the level of involvement of the interpreter and power balances. And finally, as mentioned before, it has become highly relevant to strive to make research with children as participatory as possible. For this project then, I involved NGO experts and an artist in the creation of the board games. The participants had also the possibility of creating new app "buttons" on the spot, which some of them did, for instance when adding the "button" for VClass, a learning platform used in Swedish schools. However, the daily activities in the "app o'clock" board game were pre-set (e.g., having breakfast, going to school). In a truly participatory fashion that looks beyond rationally designed activities, one could co-create these board games with the unaccompanied refugee children, based on the activities they deem important to appear on the board. This would ensure that these children's views will be not be forgotten, because as Donovan (2017) writes "wherever the future takes us, board games will be there, mirroring our choices and our attitudes on paper and cardboard" (p. 256).

\section{Concluding Thoughts}

As researchers, we must continually examine our research approaches and the field-sites in which we operate. This is even more important when doing research with vulnerable groups. Moreover, we must not accept that these approaches are just there, but we must continually be critical of the conditions which brought them about and make the necessary changes in order to meet the needs of our participants. Through this research project I realised that I need to think out of the box and create a research tool that speaks a universal language: that of "play". The ultimate aim of the board games was, of course, to collect data that can inform the creation of media literacy education programs for refugee children. However, the way this data was collected helped in creating an environment that was both safe and at times, whimsical for the participants. This is not to say that traditional interview tools should be replaced when working with refugees. However, I argue for a greater openness in bringing in tools from other aspects of life in order to not to just collect research data from our participants, 
but to offer them something in return. In this case, it was perhaps a short respite of playfulness. Denzin (2016) argues "this is a historical present that cries out for emancipatory visions, for visions that inspire transformative inquiries, and for inquiries that can provide the moral authority to move people to struggle and resist oppression" (p. 8). One small step towards this is to modify our research tools in order to create collaborative spaces for those who have been voiceless for a long time.

\section{Acknowledgments}

This project has received funding from the EU's Horizon 2020 research and innovation programme under the Marie Sklodowska-Curie grant agreement No 747083. The author thanks the anonymous reviewers for their helpful comments and Stephen Andriano-Moore for editing the manuscript.

\section{Conflict of Interests}

The author declares no conflict of interests.

\section{References}

Alencar, A. (2017). Refugee integration and social media: A local and experiential perspective. Information, Communication \& Society, 21(11), 1588-1603. https://doi.org/10.1080/1369118x.2017.1340500

Andersson, S., Aptekar, L., Boal, A., Brostrom, S., Bruner, J., Chambers, A., . . . Yardley, K. (2005). Creative methodologies in participatory research with children. In S. Greene \& D. Hogan (Eds.), Researching children's experience (pp. 254-272). London: SAGE. https://doi.org/10.4135/9781849209823

Beneito-Montagut, R. (2011). Ethnography goes online: Towards a user-centred methodology to research interpersonal communication on the internet. Qualitative Research, 11(6), 716-735.

Bergen, N. (2018). Narrative depictions of working with language interpreters in cross-language qualitative research. International Journal of Qualitative Methods, 17(1). https://doi.org/10.1177/ 1609406918812301

Berger, R., \& Zezulkova, M. (2016). A remaking pedagogy: Adaptation and archetypes in the child's multimodal reading and writing. Education 3-13, 46(1), 64-75. https://doi.org/10.1080/03004279.2016.1178316

Blay, Y. A. (2008). All the 'Africans' are men, all the "sistas" are "American," but some of us resist: Realizing African feminism(s) as an Africological research methodology. The Journal of Pan African Studies, 2(2), 58-73.

Block, K., Warr, D., Gibbs, L., \& Riggs, E. (2013). Addressing ethical and methodological challenges in research with refugee-background young people: Reflections from the field. Journal of Refugee Studies, 26(1), 69-87.
Bourdieu, P. (1996). Understanding. Theory, Culture and Society, 13(2), 17-37.

Boyd, D. (2014). It's complicated: The social lives of networked teens. New Haven, CT: Yale University Press.

Cannella, G. S. (1997). Deconstructing early childhood education: Social justice and revolution. New York, NY: Peter Lang.

Carter, S., \& Mankoff, J. (2005). When participants do the capturing. The role of media in diary studies. Paper presented at $\mathrm{CHI}$, Portland, USA. Retrieved from http://www.madpickle.net/scott/pubs/carterdiary-05.pdf

Charmarkeh, H. (2013). Social media usage, tahriib (migration), and settlement among Somali refugees in France. Refuge: Canada's Journal on Refugees, 29(1), 43-52.

Chou, M. (2017). Board games play matters: A rethinking on children's aesthetic experience and interpersonal understanding. Eurasia Journal of Mathematics Science and Technology Education, 13(6), 2405-2421.

den Besten, O. (2010). Local belonging and 'geographies of emotions': Immigrant children's experience of their neighbourhoods in Paris and Berlin. Childhood, 17(2), 181-195.

Denzin, N. K. (2016). Critical qualitative inquiry. Qualitative Inquiry, 23(1), 8-16.

Driscoll, S. (2018). Card and board games. Salem Press Encyclopedia. Retrieved from http://search. ebscohost.com/login.aspx?direct=true \&db=ers\&AN $=100259056 \&$ site $=$ eds-live

Doná, G. (2007). The microphysics of participation in refugee research. Journal of Refugee Studies, 20(2), 210-229.

Donovan, T. (2017). It's all a game: The history of board games from Monopoly to Settlers of Catan. New York, NY: Thomas Dunne Books.

Ellis, B. H., Kia-Keating, M., Siraad, A. Y., Lincoln, A., \& Nur, A. (2007). Ethical research in refugee communities and the use of community participatory methods. Transcultural Psychiatry, 44(3), 459-481.

Ellis, C. (2007). Telling secrets, revealing lives. Relational ethics in research with intimate others. Qualitative Inquiry, 13(1), 3-29.

El-Shaarawi, N. R. (2012). Living an uncertain future: an ethnography of displacement, health, psychosocial well-being and the search for durable solution among Iraqi refugees in Egypt (Doctoral dissertation). Case Western Reserve University, Cleveland, USA. Retrieved from https://etd.ohiolink.edu/!etd.send_ file?accession=case $1325709084 \&$ disposition=inline

Eurostat. (2016). Almost 90,000 unaccompanied minors among asylum seekers registered in the $E U$ in 2015 (87/2016). Luxembourg: Eurostat Press Office. Retrieved from http://ec.europa.eu/eurostat/ documents/2995521/7244677/3-02052016-APEN.pdf

Eurostat. (2017). Asylum applicants considered to be unaccompanied minors: Annual data. Eurostat. 
Retrieved from http://ec.europa.eu/eurostat/tgm/ table.do?tab=table\&init=1\&language=en\&pcode= tps00194\&plugin $=1$

Ferguson, R., Coughlan, T., Egelandsdal, K., Gaved, M., Herodotou, C., Hillaire, G., . . . Whitelock, D. (2019). Innovating pedagogy 2019: Open university innovation report 7. Milton Keynes: The Open University.

Fernandez, S., Liamputtong, P., \& Wallersheim, D. (2015). What makes people sick: Burmese refugee children's understanding of health and illness. Health Promotion International, 30(1), 151-161.

Fink, E. (1960). The ontology of play. Philosophy Today, 4(2), 95-109.

FitzGerald, D. (2012). A comparativist manifesto for international migration studies. Ethnic and Racial Studies, 35(10), 1725-1740.

Francisco, V. (2014). "Ang Ating lisang Kuwento" our collective story: Migrant Filipino workers and participatory action research. Action Research, 12(1), 78-93.

Gauntlett, D. (2007). Creative explorations: New approaches to identities and audiences. London: Routledge.

Gillespie, M., Ampofo, L., Cheesman, M., Faith, B., Iliadou, E., Issa, A., . . . Skleparis, D. (2016). Mapping refugee media journey: Smartphones and social media networks (Research Report). Milton Keynes and Issy-les-Moulineaux: The Open University and France Médias Monde. Retrieved from https://www.open.ac.uk/ccig/sites/www.open. ac.uk.ccig/files/Mapping\%20Refugee\%20Media\% 20Journeys\%2016\%20May\%20FIN\%20MG_0.pdf

Greene, S., \& Hogan, D. (2005). Researching children's experience: Methods and methodological issues. In S. Greene \& D. Hogan (Eds.), Researching children's experience: Approaches and methods (pp. 2-21). London: Sage. https://doi.org/10.4135/9781849209823

Hopkins, P. (2008). Ethical issues in research with unaccompanied asylum-seeking children. Children's Geographies, 6(1), 37-48.

Hovil, L., Lomo, Z., \& Kaiser, T. (2005). 'We are stranded here together': Freedom of movement, settlements, and self-settled refugees in Arua and Moyo districts (Refugee Law Project Working Paper, No. 14). Kampala: Refugee Law Project.

Huizinga, J. (1949). Homo Ludens. A study of the playelement in culture. London: Routledge \& Kegan Paul.

Jacobsen, K., \& Landau, L. B. (2003). The dual imperative in refugee research: Some methodological and ethical considerations in social science research on forced migration. Disasters, 27(3), 185-206.

James, A., \& Prout, A. (Eds.). (1997). Constructing and reconstructing childhood. London: Falmer Press.

Kabranian-Melkonian, S. (2015). Ethical concerns with refugee research. Journal of Human Behaviour in the Social Environment, 25(7), 714-722.

Kohli, R., \& Mather, R. (2003). Promoting psychosocial well-being in unaccompanied asylum-seeking young people in the United Kingdom. Child \& Family Social
Work, 8(3), 201-212.

Kutscher, N., \& Kreß, L. M. (2018). The ambivalent potentials of social media use by unaccompanied minor refugees. Social Media Society, 4(1), 1-10. https:// doi.org/10.1177/2056305118764438

Ladur, A. N., van Teijlingen, E., \& Hundley, V. (2018). Whose shoes? Can an educational board game engage Ugandan men in pregnancy and childbirth? BMC Pregnancy and Childbirth, 18(1), 1-8.

Lambotte, F., \& Meunier, D. (2013). From bricolage to thickness: Making the most of the messiness of research narratives. Qualitative Research in Organizations and Management: An International Journal, 8(1), 85-100. https://doi.org/10.1108/ 17465641311327531

Leurs, K., Omerovic, E., Bruinenberg, H., \& Sprenger, S. (2018). Critical media literacy through making media: A key to participation for young migrants? Communications: European Journal of Communication Research, 43(3), 427-450. https://doi.org/10.1515/ commun-2018-0017

Leurs, K., \& Smets, K. (2018). Five questions for digital migration studies: Learning from digital connectivity and forced migration in(to) Europe. Social Media + Society, 4(1), 1-16. https://doi.org/10.1177/ 2056305118764425

Liamputtong, P., \& Fernandez, S. (2015). The drawing method and Burmese refugee children's perceptions of health and illness. Australasian Journal of Early Childhood, 40(1), 23-32.

Livingstone, S., \& Sefton-Green, J. (2016). The class: Living and learning in the digital age. New York, NY: New York University Press.

MacNaughton, G., \& Smith, K. (2015). Transforming research ethics: The choices and challenges of researching with children. In S. Richards, J. Clark, \& A. Boggis (Eds.), Ethical research with children. New York, NY: Palgrave Macmillan.

Morawska, E. (2018). Qualitative migration research: Viable goals, open-ended questions, and multidimensional answers. In E. Yalaz \& Zapata-R. Barrero (Eds.), Qualitative research in European migration studies (pp. 113-143). New York, NY: Springer Open.

Moskal, M. (2017). Visual methods in research with migrant and refugee children. In P. Liamputtong (Ed.), Handbook of research methods in health social science (pp. 1-16). Singapore: Springer.

Mouton, A., Gillet, N., Mouton, F., Van Kann, D., Bruyère, O., Cloes, M., \& Buckinx, F. (2017). Effects of a giant exercising board game intervention on ambulatory physical activity among nursing home residents: a preliminary study. Paper presented at ECSS MetropolisRuhr, Essen. Retrieved from https://orbi. uliege.be/handle/2268/212895

O'Donoghue, D. (2011). Doing and disseminating visual research: Visual arts-based approaches. In E. Margolis \& L. Pauwels (Eds.), The Sage handbook of visual research methods (pp. 638-650). London: Sage. 
O'Loughlin, M. (2001). The development of subjectivity in young children: Some theoretical and pedagogical considerations. Contemporary Issues in Early Childhood, 2(1), 49-65.

Sack, W. (1998). Multiple forms of stress in refugee and immigrant children. Child and Adolescent Psychiatric Clinics of North America, 7(1), 153-167.

Schmidt, A. (2007). I know what you're doing': Reflexivity and methods in refugee studies. Refugee Survey Quarterly, 26(3), 82-99.

Slattery, P., \& Rapp, D. (2003). Ethics and the foundations of education: Teaching convictions in a postmodern world. Boston, MA: Allyn \& Bacon.

UNICEF. (2017). The state of the world's children 2017: Children in a digital world. New York, NY: UNICEF. Retrieved from https://www.unicef.org/publications/ index_101992.html

Vaart, G. V. D., Hoven, B. V., \& Huigen, P. P. (2018). Creative and arts-based research methods in academic research: Lessons from a participatory research project in the Netherlands. Forum: Qualitative Social Research, 19(2), 1-30. https://doi.org/10.17169/fqs19.2.2961

Vittadini, N., Carlo, S., Gilje, $\varnothing$., Laursen, D., Murru, M. F., \& Schrøder, K. C. (2014). Multi-method and innovative approaches to researching the learning and social practices of young digital users. International Journal of Learning and Media, 4(2), 33-45.

Voutira, E., \& Doná, G. (2007). Refugee research methodologies: Consolidation and transformation of a field. Journal of Refugee Studies, 20(2), 163-171.

Wu, C., Chen, G., \& Huang, C. (2014). Using digital board games for genuine communication in EFL classrooms. Educational Technology Research and Development, 62(2), 209-226.

Yalaz, E., \& Zapata-Barrero, R. (2018). Mapping the qualitative migration research in Europe: An exploratory analysis. In E. Yalaz \& Zapata-R. Barrero (Eds.), Qualitative research in European migration studies ( $\mathrm{pp}$. 9-35). New York, NY: Springer Open.

\section{About the Author}

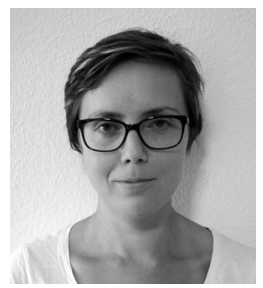

Annamária Neag is a Marie Curie Research Fellow at Bournemouth University. Her research project is looking at how unaccompanied refugee children use digital and social media. The aim of the project is to develop media literacy education tools that can help unaccompanied refugee children's integration into their new culture and society. Her research interests include media literacy education, media history and digital citizenship. 